\title{
Significance of Tourism Budget, Inflation, and Interest Rate on Economic Growth in Indonesia for the Year of 2011-2020
}

\author{
Zata Hasyyati \\ Department of Economics, Faculty of Social Science, Universitas Pembangunan Panca Budi Medan, Indonesia
}

DOI: https://doi.org/10.52403/ijrr.20220122

\begin{abstract}
This study is aimed to investigate the relationship of tourism budget, inflation, interest rate on economic growth in Indonesia in 2011 2020. Data was gathered from Central Bureau of Statistics (Badan Pusat Statistik/BPS) and Ministry of Finance (Kementerian Keuangan/ Kemenkeu). The data were analyzed using the multiple regression analysis after fulfilling all of the classical assumption tests. It showed that the inflation and interest rate have significant positive impact while tourism budget has insignificant negative impact on economic growth. In this case, monetary policy tends to be efficiently implemented at the level of promoting growth. However, Indonesia is still early on hoping significant contribution of tourism sector.
\end{abstract}

Keywords: Tourism Budget, Inflation, Interest Rate, Economic Growth, GDP, Multiple Regression Analysis.

\section{INTRODUCTION}

Ensuring society's welfare is always the government's biggest challenge every year. The government's performance is always be evaluated based on the government's effort on escalating the economic growth of the country. The reason is due to the fact that economic growth has close relationship on a picture of society's welfare. In most cases, economic growth could be measured by the level of Gross Domestic Product (GDP). GDP reflects country's output during certain period of time. Therefore, the fiscal and monetary policy are formulated whether to sustain the economic stability or enhancing the plausible economic performance.

Increase on consumption indicates the society's purchasing power is much better. Consumption aspect could be caused also by the increase on government spending. The government's budget is allocated on several productive sectors such as tourism sector. Tourism sector demands lots of money since it needs well-established infrastructure. Consequently, it triggers Central Bank/Bank Indonesia (BI) determines the interest rate at the level that could balance the money supply and demand on the market as well as controlling the inflation rate. The combination of fiscal policy (government spending) and monetary policy (interest rate) should be based on what is best for the economic return for the country either in short term or long term.

Investment in tourism sector involves lots of human capital employment and physical capital utilization. Tourism sector will be followed by the establishment of hotels, restaurants, as well as gift stores which promote cultural aspect of Indonesia. Besides, ecotourism becomes most demanding tourism aspect. Indonesia, which is blessed with abundance spectacular natural resources is supposed to be the best on natural-based tourism management. Hence, due to its ability on promoting social, cultural, and economic aspect, focusing on tourism sector is a great deal for Indonesia. 
Based on World Economic Forum Report on Travel and Tourism (2019), Indonesia was rank in $40^{\text {th }}$ over 140 economies by analyzing some factors and policies that supporting the competitiveness of Indonesia in tourism sector. Indonesia has a great price competitiveness but neglecting the environmental sustainability on its tourism management which is far below and ranked in $135^{\text {th }}$. Although, Indonesia's tourism management pays a great attention on health and hygiene recently, it's still a long way to go. Furthermore, Indonesia was still ranked on $70^{\text {th }}$ on infrastructure index. Therefore, tourism budget should be prioritized on managing environmental concern and building infrastructure.

The contribution of tourism sector is relatively stable on economic growth. Attracting more tourists means the potential demand on domestic currency and goods which are good for the economy.

Recently, budget allocation on tourism sector becomes more 'appealing' for developing countries since its contribution as the fourth largest source of export revenue. Long-term relationship of tourism spending and economic growth has been confirmed to be true based on Seghir, et.al. (2015) in 1988 - 2012. The research also evaluated the impact of some uncertain situation such as bad news on tourism activity in those countries. Seghir, et.al. suggest the investors and mangers supposed to evaluate the causality results among the tourism sector, uncertain situation and economic growth to identify perfect timing of investment and business strategy implementation.

In the beginning of 1990s, tourism might not a priority of government's budget allocation since the portion of tourism budget is only less than 5 percent annually. Nevertheless, near to year 2000s, there was significant change on investing more in tourism sector. The trend had been increasing positively until 2019 with its significant contribution around 7.42\% (BPS, 2004). In developing countries, government intervention on the economy is still the biggest source of the development process. Therefore, maximizing budget allocation at its potential return is greatly demanded to boost the value of Gross Domestic Product. One of the potential returns that could be considered is tourism sector.

These phenomena lead to the researchers' consideration on analyzing the relationship among tourism budget, inflation, interest rate, and economic growth in Indonesia. These time series data are analyzed using the multiple regression model by EVIEWS. The data of tourism spending, inflation, interest rate, and economic growth in Indonesia were gathered from Bureau Statistic (BPS) and Ministry of Finance (Kementerian Keuangan/ Kemenkeu) Indonesia from 2011 - 2020.

\section{LITERATURE REVIEW}

Fisher (1930) stated that interest rate is a reference of a currency's performance. Interest rate is vital on determining the appreciation and depreciation of currency based on the comparison among countries that have an economic transaction. High level of domestic nominal interest rate causes the domestic currency to be depreciated by the other country's currency. In this case, the inflation rate moves higher as the nominal interest rate is increasing. It can be concluded that the interest rate and inflation move in the same direction while it has an inverse effect on the value of currency.

Furthermore, Alam, et. al (2011) evaluates the empirical evidence of International Fisher Effect implication among Bangladesh with India and China in time series approach. In fact, International Fisher Effect was not reflected on this relationship during 1995 - 2008. The plausible explanation of the situation is because the money market was not totally free access across border. Some factors such as politics, psychological aspect, transaction cost are the barriers in the money market. It 
violates the International Fisher Effect assumption to be truly acceptable.

Saymeh and Orabi (2013) examines the relationship of interest rate, inflation rate, and Gross Domestic Product in Jordan using Johansen test from 2000 - 2010. All variables show the results of being co integrated. Interest rate was affected by inflation based on Granger Causality analysis.

Bhunia (2016) evaluated how inflation and interest could be related to economic growth. By applying co integration test, vector error correction model, and granger causality test, it shows that there is a long run relationship among these variables in India. From 1992 to 2015, there is significant correlation between interest rate and economic growth. Therefore, evaluating India's economic policy on maintaining inflation and interest rate stable will support the economic growth.

Babalola, et.al. (2015) also investigated inflation and interest rate effect on Nigeria's economy. Global recovery from the recession had been big challenges to Nigeria as developing countries which cause delay on its effort improving economic growth. The research showed that inflation and interest rate have negative impact on economic growth. In other words, the higher rate of interest and inflation will have detrimental effect on economic growth to fall. Thus, it is much desirable for the developing countries to control its inflation rate at a single digit to attract more capital inflow for the economic development.

Furthermore, Mandala, RAM (2015) added government expenditure as independent variable to check how significant the role of this variable on economi growth. By applying Engel Granger Co integration Test and Error Correction Model, it showed that either in short run or long run, government expenditure has significant positive impact on GDP. However, it is applied only for the allocation on strategic plan such as investment.
In Saudi Arabia, the empirical evidence in 2003 - 2009 showed a long run relationship between economic growth and tourism indicators. The most significant aspect for the GDP is tourism arrivals. Promoting tourism in Saudi Arabia should be based on easing the access either in form of infrastructure or document applications (Naseem, 2021).

Nevertheless, the increase on government spending could affect the inflation rate to be higher because of the demand on money market. However, interest rate has a role on controlling the inflation rate. Increasing the interest rate causes people to save more. Hence, the inflation will be decreased.

\section{MATERIALS \& METHODS}

The data in this research were analyzed using the multiple regression analysis for a 10 - year period start from 2011 to 2019. Inflation, interest rate, and GDP are gathered from Bureau of Statistic (Badan Pusat Statistik / BPS). Meanwhile, the tourism budget data were a quantitative data which is collected from Ministry of Finance (Kementerian Keuangan/ Kemenkeu). There are four variables collected in this research (Table 1).

Table1 Variables

\begin{tabular}{|l|l|l|}
\hline No & Variables & Unit \\
\hline 1. & GDP growth in Indonesia from 2011 - 2020 & IDR \\
\hline 2. & Inflation in Indonesia 2011 - 2020 & $\%$ \\
\hline 3. & Interest rate in Indonesia from 2011-2020 & $\%$ \\
\hline 4. & Tourism budget from 2011 - 2020 & IDR \\
\hline
\end{tabular}

The important aspect of using multiple regressions analysis is fulfilling the classical assumption test about the normality distribution of data, autocorrelation, multicollinearity, and heteroscedasticity (Gujarati, 2003).

\section{Data Analysis and Processing Method}

This research is a quantitative analysis with statistical modeling using multiple regression analysis to evaluate the tourism budget, inflation, interest rate and economic growth. The formula is as follows $\mathrm{GDPt}=\alpha 0+\beta 1 \mathrm{IFt}+\beta 2 \mathrm{IRt}+\beta 3 \mathrm{TBt}+$ et $(1)$ 
Zata Hasyyati. Significance of tourism budget, inflation, and interest rate on economic growth in Indonesia for the year of $2011-2020$.

$$
\begin{array}{ll}
\text { GDP } & \text { : economic growth } \\
\text { IF } & : \text { inflation } \\
\text { IR } & \text { : interest rate } \\
\text { TB } & \text { : tourism budget } \\
\alpha & : \text { a constant } \\
\beta 1, \beta 2, & \beta 3 \quad \text { : the regression coefficient } \\
\text { e } \quad \text { : error }
\end{array}
$$

\section{RESULTS AND DISCUSSIONS}

Classical assumption test is a must to assure the parameters fulfill the criteria of
BLUE (Best Linier Unbiased Estimator). The results of the model as follow:

\section{Probability Test}

As shown below, the value of skewness is -0.411 which is bigger than -2 and kurtosis is 1.82 which is smaller than 2 indicates that the data were normally distributed. It is also strengthened by the value of Jaque - Bera 0.859 which is less than the chi square table (5.99146) at the significance level of 0.05

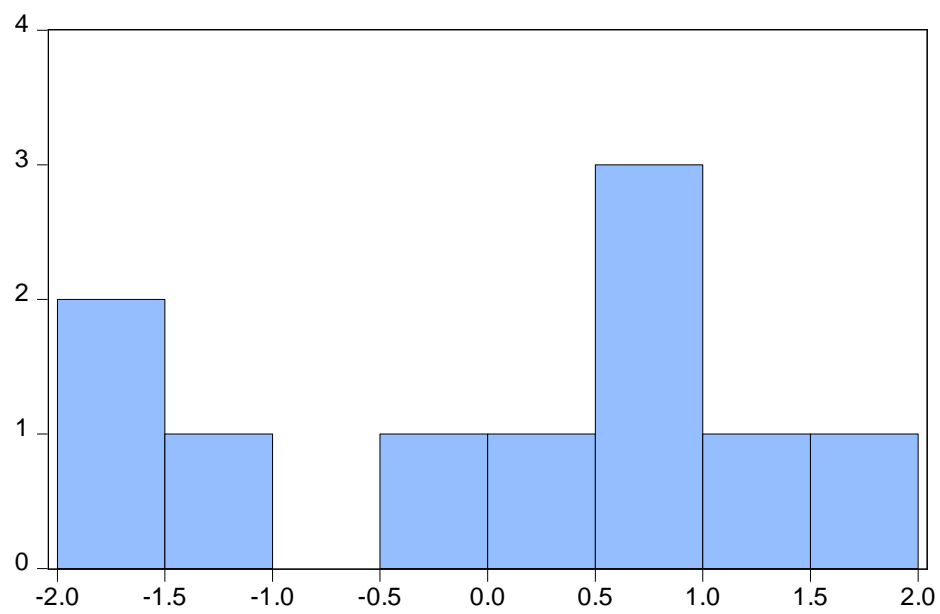

\begin{tabular}{|lr|}
\hline \multicolumn{2}{|l|}{ Series: Residuals } \\
Sample 110 \\
Observations & 10 \\
& \\
Mean & $4.44 \mathrm{e}-16$ \\
Median & 0.498550 \\
Maximum & 1.759321 \\
Minimum & -1.898979 \\
Std. Dev. & 1.305501 \\
Skewness & -0.411000 \\
Kurtosis & 1.822446 \\
& \\
Jarque-Bera & 0.859299 \\
Probability & 0.650737 \\
\hline
\end{tabular}

\section{Autocorrelation Test}

Based on table below, the value of prob.chi - square (2) is 0.0819 , bigger than 0.05 which means we accept the alternative hypothesis. In conclusion, there is no serial correlation in this data.

Tabel 2 Autocorrelation Test Breusch-Godfrey Serial Correlation LM Test:

\begin{tabular}{|l|c|c|c|}
\hline F-statistic & 2.004384 & Prob. F(2,4) & 0.2495 \\
\hline Obs*R-squared & 5.005474 & Prob. Chi-Square(2) & 0.0819 \\
\hline
\end{tabular}

\section{Heteroskedasticity test}

Heteroskedasticity test could be conducted in several methods. One of the most frequently used is Breusch - Pagan Godfrey test. Null hypothesis will lead to the conclusion that there is no heteroscedasticity in the model. Therefore, if the probability value is less than 0.05 , it means the model has heteroskedasticity.

Based on table......... , the probability chi - square of Obs*R-squared greater than 0.05 which means the

\begin{tabular}{|c|c|c|c|}
\hline \multicolumn{4}{|c|}{$\begin{array}{c}\text { Tabel 4. Variance Inflation Factor } \\
\text { Variance Inflation Factors }\end{array}$} \\
\hline \multicolumn{3}{|c|}{ Date: $12 / 28 / 21$ Time: $12: 18$} & \\
\hline \multicolumn{3}{|c|}{ Sample: 110} & \\
\hline \multicolumn{3}{|c|}{ Included observations: 10} & \\
\hline & Coefficient & Uncentered & Centered \\
\hline Variable & Variance & VIF & VIF \\
\hline $\mathrm{C}$ & 24.90931 & 97.43530 & NA \\
\hline TB & 9.33E-08 & 4.589351 & 1.835048 \\
\hline IF & 0.164749 & 11.87884 & 1.854635 \\
\hline IR & 0.352927 & 71.66924 & 2.390995 \\
\hline
\end{tabular}
alternative hypothesis is accepted. The results show the dataset is good because it is homoscedastic.

Table 3. Heteroskedasticity Test

\begin{tabular}{|l|c|c|c|}
\hline \multicolumn{4}{|l|}{ Heteroskedasticity Test: Breusch-Pagan-Godfrey } \\
\hline F-statistic & 0.796194 & Prob. F(3,6) & 0.5393 \\
\hline Obs*R-squared & 2.847421 & Prob. Chi-Square(3) & 0.4158 \\
\hline Scaled explained SS & 0.421533 & Prob. Chi-Square(3) & 0.9358 \\
\hline
\end{tabular}

\section{Multicollinearity}

Multicollinearity could be checked on the value of Centered Variance Inflation Factor. Based on the table below, all the centered VIF values for each independent variable is lower than 10 . For instance, Centered VIF for tourism budget is 1.835. It 
Zata Hasyyati. Significance of tourism budget, inflation, and interest rate on economic growth in Indonesia for the year of $2011-2020$.

is lower than 10. It also applies for all variables. It indicates there is no multicollinearity in the model. Besides, multicollinearity can also be detected by comparing R-squared of dependent variable (Y) with all independent variables. If the result is the $\mathrm{R}$-squared value of dependent variable is higher, there is no multicollinearity in the model. The $\mathrm{R}-$ squared value of dependent variable is 0.708 which is much higher than the rest.

Tabel 5. Multicollinearity R - Squared

\begin{tabular}{|c|c|c|c|c|}
\hline \multicolumn{3}{|c|}{ Dependent Variable: GDP } & & \\
\hline \multicolumn{3}{|c|}{ Method: Least Squares } & & \\
\hline \multicolumn{3}{|c|}{ Date: $12 / 28 / 21$ Time: $12: 22$} & & \\
\hline \multicolumn{2}{|l|}{ Sample: 110} & & & \\
\hline \multicolumn{3}{|c|}{ Included observations: 10} & & \\
\hline Variable & Coefficient & Std. Error & t-Statistic & Prob. \\
\hline TB & -0.000164 & 0.000305 & -0.537593 & 0.6102 \\
\hline IF & 1.468359 & 0.405892 & 3.617608 & 0.0111 \\
\hline IR & 1.664277 & 0.594077 & 2.801451 & 0.0311 \\
\hline $\mathrm{C}$ & -12.55484 & 4.990923 & -2.515534 & 0.0456 \\
\hline R-squared & 0.708843 & \multicolumn{2}{|c|}{ Mean dependent var } & 4.575000 \\
\hline Adjusted R-squared & 0.563264 & \multicolumn{2}{|c|}{ S.D. dependent var } & 2.419432 \\
\hline S.E. of regression & 1.598905 & \multicolumn{2}{|c|}{ Akaike info criterion } & 4.065690 \\
\hline Sum squared resid & 15.33898 & \multicolumn{2}{|c|}{ Schwarz criterion } & 4.186724 \\
\hline Log likelihood & -16.32845 & \multicolumn{2}{|c|}{ Hannan-Quinn criter. } & 3.932916 \\
\hline F-statistic & 4.869144 & \multicolumn{2}{|c|}{ Durbin-Watson stat } & 1.427559 \\
\hline Prob(F-statistic) & 0.047704 & & & \\
\hline \multicolumn{5}{|c|}{ Dependent Variable: TB } \\
\hline \multicolumn{5}{|c|}{ Method: Least Squares } \\
\hline \multicolumn{5}{|c|}{ Date: $12 / 28 / 21$ Time: $12: 24$} \\
\hline \multicolumn{5}{|l|}{ Sample: 110} \\
\hline \multicolumn{5}{|c|}{ Included observations: 10} \\
\hline Variable & Coefficient & Std. Error & t-Statistic & Prob. \\
\hline $\mathrm{C}$ & -3236.713 & 6055.029 & -0.534550 & 0.6095 \\
\hline IF & -203.1082 & 496.4820 & -0.409095 & 0.6947 \\
\hline IR & 957.8871 & 639.9931 & 1.496715 & 0.1781 \\
\hline R-squared & 0.455055 & \multicolumn{2}{|c|}{ Mean dependent var } & 2747.900 \\
\hline Adjusted R-squared & 0.299356 & S.D. dep & ndent var & 2364.272 \\
\hline S.E. of regression & 1979.001 & Akaike i & fo criterion & 18.26190 \\
\hline Sum squared resid & 27415113 & Schwarz & riterion & 18.35267 \\
\hline Log likelihood & -88.30948 & Hannan- & Luinn criter. & 18.16232 \\
\hline F-statistic & 2.922667 & Durbin-I & atson stat & 2.250774 \\
\hline Prob(F-statistic) & 0.119463 & & & \\
\hline Dependent Variable: & & & & \\
\hline Method: Least Squar & & & & \\
\hline Date: $12 / 28 / 21$ Tim & $12: 25$ & & & \\
\hline Sample: 110 & & & & \\
\hline Included observation & 10 & & & \\
\hline Variable & Coefficient & Std. Error & t-Statistic & Prob. \\
\hline $\mathrm{C}$ & 9.448630 & 2.974159 & 3.176909 & 0.0156 \\
\hline IR & -0.732456 & 0.478946 & -1.529309 & 0.1700 \\
\hline TB & -0.000115 & 0.000281 & -0.409095 & 0.6947 \\
\hline R-squared & 0.460810 & Mean de & endent var & 3.944000 \\
\hline Adjusted R-squared & 0.306756 & S.D. dep & ndent var & 1.788216 \\
\hline S.E. of regression & 1.488891 & Akaike i & fo criterion & 3.877265 \\
\hline Sum squared resid & 15.51757 & Schwarz & riterion & 3.968041 \\
\hline Log likelihood & -16.38633 & Hannan- & Quinn criter. & 3.777685 \\
\hline F-statistic & 2.991223 & Durbin-I & atson stat & 0.489934 \\
\hline Prob(F-statistic) & 0.115105 & & & \\
\hline Dependent Variable: & & & & \\
\hline Method: Least Squar & & & & \\
\hline Date: $12 / 28 / 21$ Tim & $12: 25$ & & & \\
\hline Sample: 110 & & & & \\
\hline Included observatio & 10 & & & \\
\hline Variable & Coefficient & Std. Error & t-Statistic & Prob. \\
\hline $\mathrm{C}$ & 7.737032 & 1.237365 & 6.252827 & 0.0004 \\
\hline TB & 0.000253 & 0.000169 & 1.496715 & 0.1781 \\
\hline IF & -0.341915 & 0.223575 & -1.529309 & 0.1700 \\
\hline R-squared & 0.581764 & Mean de & endent var & 7.084000 \\
\hline Adjusted R-squared & 0.462268 & S.D. dep & ndent var & 1.387229 \\
\hline
\end{tabular}


Zata Hasyyati. Significance of tourism budget, inflation, and interest rate on economic growth in Indonesia for the year of $2011-2020$.

\begin{tabular}{|l|l|l|l|}
\hline \multicolumn{5}{|c|}{ Table 5 Continued... } \\
\hline S.E. of regression & 1.017258 & Akaike info criterion & 3.115424 \\
\hline Sum squared resid & 7.243696 & Schwarz criterion & 3.206199 \\
\hline Log likelihood & -12.57712 & Hannan-Quinn criter. & 3.015843 \\
\hline F-statistic & 4.868482 & Durbin-Watson stat & 1.303803 \\
\hline Prob(F-statistic) & 0.047312 & & \\
\hline
\end{tabular}

\section{RESULT}

After fulfilling the classical assumption test and goodness of fit model, the regression results are as follow:

Table 6. Regression Analysis

\begin{tabular}{|c|c|c|c|c|}
\hline \multicolumn{5}{|c|}{ Dependent Variable: PDB } \\
\hline \multicolumn{5}{|l|}{ Method: Least Squares } \\
\hline \multicolumn{5}{|c|}{ Date: $12 / 28 / 21$ Time: $12: 15$} \\
\hline \multicolumn{5}{|l|}{ Sample: 110} \\
\hline \multicolumn{5}{|c|}{ Included observations: 10} \\
\hline Variable & Coefficient & Std. Error & t-Statistic & Prob. \\
\hline $\mathrm{C}$ & -12.55484 & 4.990923 & -2.515534 & 0.0456 \\
\hline TB & -0.000164 & 0.000305 & -0.537593 & 0.6102 \\
\hline IF & 1.468359 & 0.405892 & 3.617608 & 0.0111 \\
\hline IR & 1.664277 & 0.594077 & 2.801451 & 0.0311 \\
\hline R-squared & 0.708843 & \multicolumn{2}{|c|}{ Mean dependent var } & 4.575000 \\
\hline Adjusted R-squared & 0.563264 & \multicolumn{2}{|c|}{ S.D. dependent var } & 2.419432 \\
\hline S.E. of regression & 1.598905 & \multicolumn{2}{|c|}{ Akaike info criterion } & 4.065690 \\
\hline Sum squared resid & 15.33898 & \multicolumn{2}{|c|}{ Schwarz criterion } & 4.186724 \\
\hline Log likelihood & -16.32845 & \multirow{2}{*}{\multicolumn{2}{|c|}{$\begin{array}{l}\text { Hannan-Quinn criter. } \\
\text { Durbin-Watson stat }\end{array}$}} & 3.932916 \\
\hline F-statistic & 4.869144 & & & 1.427559 \\
\hline Prob(F-statistic) & 0.047704 & & & \\
\hline
\end{tabular}

Based on the table above, the tourism budget had insignificant negative impact on economic growth while the inflation and interest rate have significant positive impact on GDP.

\section{DISCUSSION}

Based on these results, inflation rate has significant positive effect on economic growth. Some previous researches are also ended with the same conclusion. There is a positive relationship of inflation on economic growth in OECD Countries 1960 - 2012 (Pradhan, 2015) and Finland (Sattarov, 2011). Blanchard and Kiyotaki (1987) stated the plausibility of this positive relationship because of some agreed deals by some firms to supply good at an agreed time and price. It happens also in South African Customs Unions (SACU) region 1991 - 2018. Taderera, et.al. (2021), stated that it is desirable to keep the inflation high at the desirable point of promoting economic growth. Targeted inflation rate in financial markets is still a strategic policy that could be beneficial as long as it is controlled by the monetary policy of central bank through the interest rate. Based on the regression results, the interest rate also has a positive relationship which means it moves at the same direction of the inflation rate. During 2011 - 2020, it might be the case where Central Bank (Bank Indonesia/BI) could maintain its level of inflation rate with its monetary policy through interest rate at the range that is sustainable for the economic growth.

On the other hand, the tourism budget has insignificant negative relationship on economic growth. It can be caused because the tourism sector invests lots on infrastructure which in short term, the effect tends to be negative. The negative impact could be due to the contribution of investment in tourism cannot be enjoyed at the moment of spending is made. Therefore, the expenditure is relatively much higher than the return which in turn causes the economic growth to be negative. In this case, long run relationship analysis could be applied. Achyar, DH, Hakim, DB (2021) found long run causal relationship between tourism sector and GDP in Aceh Province, Indonesia. Besides, Holik (2016), in 
Zata Hasyyati. Significance of tourism budget, inflation, and interest rate on economic growth in Indonesia for the year of $2011-2020$.

ASEAN countries as well, it shows positive relationship between tourism sectors and economic growth. Tourism sector is closely related to the mechanism of exchange rate stabilization. High exchange rate will cause the decrease on the number of visitors which affect the tourism business. Hence, it is essential maintaining a stable economy while sustaining the tourism vitality.

\section{CONCLUSION}

The study investigates the relationship among tourism budget, inflation, interest rate on economic growth using the multiple regression analysis. The observation is in Indonesia during 2011 2020. Inflation and interest rate have significant positive effect while tourism budget has insignificant negative impact on GDP.

Policy implication that can be derived from this result is the government seems to be successful on controlling the inflation. Monetary policy that had been taken was effectively keeping the inflation rate at the desirable level. Nevertheless, it is should be noted that although the tourism sector seems to be inversely affect the economic growth in short run relationship, it is profitable at the long run. Investment and government's allocation on tourism sector is still on a very early stage of development process to be profitable. However, looking at the increasing trend on tourism contribution on GDP, it is still worth a strategic post consideration of government's budget. Therefore, prioritizing on most potential infrastructure and strategic plan of tourism sector is needed.

Acknowledgement: None

Conflict of Interest: None

Source of Funding: None

\section{REFERENCES}

1. [BPS] Badan Pusat Statistik. 2004. Dalam Angka. Banda : BPS Provinsi

2. [BPS] Badan Pusat Statistik. 2018. Dalam Angka. Banda : BPS Provinsi

3. [Kemenkeu] Kementrian Keuangan. 2016. Efektivitas Alokasi Anggaran

4. Kementrian Pariwisata terhadap Kunjungan Wisatawan Mancanegara dan Wisatawan Nusantara. Jakarta : Direktorat Jenderal Anggaran.

5. Achyar, DH, Hakim, DB.2021.'Cointegration Analysis of Tourism Sector, Inflation, Interest Rate and Economic Growth in Special Autonomy Region of Aceh Province, Indonesia'. International Journal of Scientific Research in Science, Engineering, and Technology. Vol 8(1).pp.216 - 221.

6. Alam, M.M., Alam, K.A., and Shuvo, A. 2011. An Empirical Evidence of International Fisher Effect in Bangladesh with India and China: A Time-Series Approach, Elixir Online Journal: Elixir Finance, Vol. 36, pp. 3078-3081.

7. Babalola, OO.,et.al.2015. 'Inflation, Interest rates, and Economic Growth in Nigeria'.European Journal of Business and Management.Vol 7(30).pp. 91-102.

8. Bhunia, A.2016.'How Inflation and Interest Rate Are Related to Economic Growth? A Case of India. Journal of Finance and Accounting. Vol.4(1). Pp. $20-26$.

9. Calderwood, LU. \& Soshkin, M.2019.The Travel and Tourism Competitiveness Report 2019: Travel and Tourism at a Tipping Point. Geneva : WorldEconomic Forum.

10. Fisher, I, 1930, The Theory of Interest, New York: Macmillan.

11. Gujarati, D. (2003). Basic Econometrics. Fourth Edition. New York: The McGraw-Hill.

12. Holik, A. 2016.'Relationship of Economic Growth with Tourism Sector'. Journal of Economics and Policy.Vol 9(1). pp. 16 - 33.

13. Kryeziu,N, Durguti, E.2019. 'The Impact of Inflation on Economic Growth: The Case of Eurozone. Journal of Finance \& Banking Studies.Vol 8(1). Pp.01-09.

14. Mandala, RAM.2020.'Inflation, Government Expenditure, Economic Growth in Indonesia.Jambura Equlibrium Journal.Vol2(2).pp.109 - 118. 
Zata Hasyyati. Significance of tourism budget, inflation, and interest rate on economic growth in Indonesia for the year of $2011-2020$.

15. Naseem, S. 2021.'The Role of Tourism in Economic Growth: Empirical Evidence from Saudi Arabia.Vol 9(117),pp. 1-12.

16. Pradhan, R.P., Arvin, M.B. and Bahmani, S., 2015. Causal nexus between economic growth, inflation, and stock market development: The case of OECD countries. Global Finance Journal, 27, pp.98-111.

17. Sattarov, K. (2011). Inflation and Economic Growth. Analyzing the Threshold Level of Inflation.: Case Study of Finland, 19802010. Master Thesis, 15 ECTS. Universitet UMEA.

18. Saymeh, F \& Orabi A 2013. 'The Effect of Interest Rate, Inflation Rate, GDP, on Real Economic Growth Rate in Jordan', Asian Economic and Financial Review,vol.3, no.3,pp. 341-354.
19. Seghir, GM., et. al.2015.'Tourism Spending-Economic Growth Causality in 49 Countries: A Dynamic Panel Data Approach', Procedia Economics and Finance, vol.23,pp. 1613 - 1623.

20. Taderera,CS., et.al.2021.'Inflation, Interest Rate, and Economic Growth Nexuses in SACU Countries'. Munich Personal RePEc Archive (MPRA). pp.1-20.

How to cite this article: Zata Hasyyati. Significance of tourism budget, inflation, and interest rate on economic growth in Indonesia for the year of 2011 - 2020. International Journal of Research and Review. 2022; 9(1): 167-174. DOI: https://doi.org/10.52403/ijrr. 20220122 